\title{
An Empirical Investigation on the Use of Information Sources for Promoting Healthy Eating
}

\author{
Eric $\mathrm{Ng}$ \\ University of Southern Queensland \\ E-Mail: eric.ng@usq.edu.au \\ Kathleen Hastings \\ Xylem International Pty Ltd \\ E-Mail: kathy@xylem.net.au
}

\begin{abstract}
This research investigates the information sources consumers used to obtain health related information for healthy eating. The research involves two stages, indepth interviews with 12 participants and a mail survey of 800 . Findings from the indepth interviews not only supported the information sources identified in the literature but had also revealed the need to include two other information sources (social organisations and societies, and health clubs and gyms) for further investigation. The mail survey indicated that friends and relatives were the most important information source used for obtaining health related information for healthy eating whilst radio was identified as the least influential. The findings highlighted the relative importance of the 15 information sources investigated and also identified the most appropriate sources for which health promoters could effectively spend their limited resources on the advertising and promotional campaigns that were targeted at specific consumer groups.
\end{abstract}

Keywords: Health Information Sources, Promoting Healthy Eating, Healthcare Marketing, Regional Australia

\section{BACKGROUND}

People who are overweight and or obese have risen significantly worldwide to global epidemic proportions. In Australia, the prevalence of overweight and obese people has been increasing dramatically over the last two decades, which has attracted 
much public attention as a health concern. A study conducted in 2004-05 revealed that about 54 per cent (as compared to 38 per cent in 1989-90) of Australian adults were classified as overweight or obese, of which 62 per cent were men whilst women accounted for 45 per cent (Australian Bureau of Statistics, 2008). A further comparison between the results of the 2004-05 study with those conducted in the preceding 15 years clearly shows that there is a gradual increase in the number and proportion of adults who are overweight or obese, resulting in the number of overweight or obese adults increased from 4.6 million in 1989-90 to 7.4 million in 2004-05 (Australian Bureau of Statistics, 2008). With this growing trend, it has estimated to cost the Australian society and governments a massive amount of \$21 billion in weight issues, and their related illnesses (Access Economics, 2006). This data shows that Australia has not been spared from the worldwide trend towards obesity that appears to be associated with modernisation and changing lifestyles (Thorburn, 2005).

Due to the growing public attention on overweight and obesity as a health concern in recent years, there has been an increasing trend towards healthier eating that led to consumer demand for more detailed, accurate and accessible health related information (ACNielson, 2005; Beuchat, 2002). Nowadays, consumers are taking a more proactive role in their healthcare and given the surge in the use of new media for health information gathering, the flow of information to consumers becomes a key determinant to their welfare. Although information alone does not necessarily result in improving health well-being, it is seen as an important step towards positive health behaviour change (Freimuth, Stein \& Kean, 1989; Kreuter, Chheda \& Bull, 2000). Furthermore, consumers are generally motivated to seek information to reduce their uncertainty by relying on reliable information sources to assist in their decision making process, in order to improve their health well being (Urbany, Dickson \& Wilkie, 1989). With the increasing convenience, accessibility and availability of health related information via various channels (e.g. media, internet), the need to understand how consumers acquire this information to make informed decisions on food choices is now more important than before, particularly when it is likely to influence buying patterns that could result in healthy eating (Srinivasan, 1990).

Although studies were conducted to investigate sources of health related information, there is an apparent lack of research into the effects of these changes in Australia, particularly in the Australian regional context, and about the information sources which consumers used to select food choices for healthy eating. The purpose of this study seeks to identify the information sources consumers used to obtain health 
related information for healthy eating and also determine their relative importance. The research findings can assist health promoters (including public and commercial entities) to identify the key sources of health information that consumers used to select food choices for healthy eating. Through this, health promoters can more effectively utilise the limited resources to develop appropriate promotional campaigns or communication channels that are directed at specific consumer groups, in order to further encourage healthy eating.

This paper begins by reviewing the literature relevant to the research issue and then discusses the methodology including the data collection techniques used in researching this issue. Next the analysis of data is described and then the findings presented. These will be followed by the conclusions drawn from the research together with the implications and suggestions for further research.

\section{LITERATURE REVIEW}

Current literature indicates that there are limited studies on health information sources in Australia, particularly in a regional context, which is the key focus of this paper. Healthy eating behaviour is regarded as volitional and the lack of knowledge or awareness of health related information could potentially prevent people from making sound decisions to eating healthily (Povey, Conner, Sparks, James \& Shepherd, 1998). Other studies have investigated several different aspects of healthy eating, such as attitudes toward healthy eating (Dibsdall, Lambert, Bobbin \& Frewer, 2003; Story et al., 2002; Verplanken \& Faes, 1999), barriers and facilitators to healthy eating (Biloukha \& Utermohlen, 2001; Kearney \& McElhone, 1999; Shepherd et al., 2006), advertising and promotional strategies for healthy eating (Ip, Mehta \& Coveney, 2007; Reger, Wootan \& Booth-Butterfield, 1999; St Leger, 1999) and policies on eating healthily (Glanz \& Hoelscher, 2004; Nestle \& Jacobson, 2000; Young, 1993).

While studies (for example Biloukha \& Utermohlen, 2001; De Almeida et al., 1997; Dutta-Bergman, 2004; Warner \& Procaccino, 2004) had been conducted on sources of health information, very few studies have been carried out in Australia (particularly in the South-East Queensland region), specifically to investigate the information sources used for obtaining health related information for healthy eating. The importance of this study is further supported by the Australian government's stance to provide funding to promote healthy eating and create healthy environments in regional Australia where fundamental problems associated with distance existed (Bell, 2008). On the basis of the literature reviewed, a preliminary framework (Figure 
1) was developed and derived from these previous health information search studies that investigate the different types of information sources.

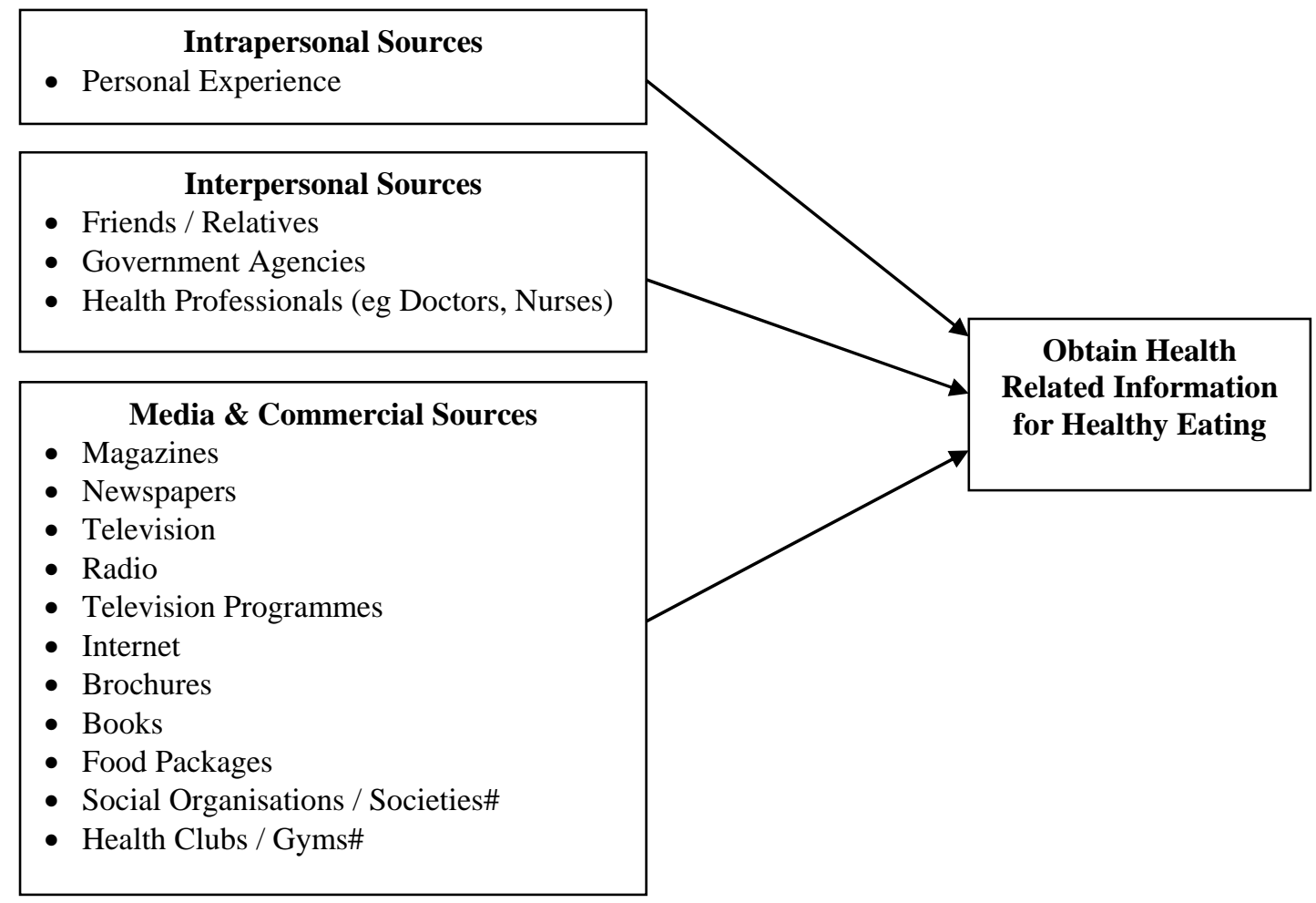

Figure 1 Preliminary framework of information sources used to obtain health related information for healthy eating

Source: Biloukha \& Utermohlen, 2001; De Almeida et al., 1997; Dutta-Bergman, 2004

Note: Based on the in-depth interview findings, information sources with a (\#) were added to the framework as important to obtain health related information for healthy eating in the Australian regional context.

Information sources that consumers use to obtain health related information for healthy eating vary and might differ in accordance to decision making situations. Studies have investigated models of information search behaviour and information source usage in different situations (for example Abbott, 1997; Lambert \& Loiselle, 2007; Theodosiou \& Green, 2003; Warner \& Procaccino, 2004). Although there is no one common classification system for health information sources, they can generally be classified into three categories: (1) intrapersonal sources, (2) interpersonal sources, (3) media and commercial sources (for example Borzekowski \& Rickert, 2001; Brown \& Walsh-Childers, 1994; Gardner, 2000; Worsley, 1989).

The literature suggested that personal experience is one of the most commonly used information sources by consumers as a passive or internal information search in 
their decision making process (Punj \& Steward, 1983; Schwarz, 2004). This internal information derived from past experience and knowledge, depending on the nature and the extent of these previous experiences could possibly influence consumer's healthy eating behaviour in the future, including the choice of food for healthy eating (Marshall, Anderson, Lean \& Foster, 1994; Story et al., 2002).

Friends and relatives were often regarded as a trustworthy and credible source of information. Due to the highly reliable nature of this information source, individuals were likely to seek information, opinions and suggestions from their friends and relatives that could assist them to make decisions on the choice of food for healthy eating (Abbott, 1997; Biloukha \& Utermohlen, 2001; De Almeida et al., 1997; Kerstetter \& Cho, 2004). Several studies (for example Lappalainen, Kearney \& Gibney, 1998; De Almeida et al., 1997; Eysenbach \& Köhler, 2002; Warner \& Procaccino, 2004) had also consistently revealed that government agencies and health professionals were among the most trusted sources of information, when obtaining health related information.

Previous studies (such as Abbott, 1997; Biloukha \& Utermohlen, 2001; DuttaBergman, 2004; Kerstetter \& Cho, 2004) highlighted that consumers used nondirected public information sources such as magazines, newspapers, television, radio and television programmes, to obtain health related information. A study conducted recently further supported this by revealing television, newspapers, magazines and radio as the top media ad spending in Australia (Veldre, 2005). Food packages were also seen as a valuable source of information to consumers particularly where health and nutrition information related to the specific product was available on the spot for further and immediate purchase consideration (Ford, Hastak, Mitra \& Ringold, 1996; Garretson \& Burton, 2000; Kozup, Creyer \& Burton, 2003; Reid \& Hendricks, 1993).

The increasing adoption and development of the internet had seen a number of studies (for example Eysenbach, Powell, Kuss \& Sa, 2002; Gray, Klein, Noyce, Sesselberg \& Cantrill, 2005; Risk \& Petersen, 2002) investigate its role in the information search process for health related information. Findings in several studies (for example Berland et al., 2001; Risk \& Dzenowagis, 2001; Theodosiou \& Green, 2003) revealed that consumers were able to exploit the many benefits (such as up-todate information, immediate and global accessibility, ease of access and connectivity, and interactivity) of utilising the internet to search for health related information. In spite of the rapid emergence of health information technology, brochures and books remain as popular information sources (Biloukha \& Utermohlen, 2001; Evans, Necheles, Longjohn \& Christoffel, 2007; Szwajcer, Hiddink, Koelen \& Van Woerkum, 
2005). Brochures generally provide brief overview of health related information whilst books give more specific details (Courtright, 2004; Freeland-Graves \& Nitzke, 2003; Kozup, Creyer \& Burton, 2003; Lappalainen, Kearney \& Gibney, 1998).

\section{RESEARCH METHOLDOLOGY}

The research methodology adopted in this study was designed primarily to overcome a lack of prior research directly related to the research problem. Due to the apparent lack of research literature about information sources on healthy eating in Australia (particularly in regional setting), it was necessary to develop propositions about the research issue. Therefore a two-stage process was adopted, firstly interviews were conducted with consumers in the regional Australia in order to determine the relevance of the current literature about the information sources consumers used in obtaining health related information for healthy eating and also to identify other issues which might be specific to healthy eating in such settings. In the second stage, a mail survey using information gathered from the first stage was conducted.

\section{In-Depth Interviews}

The adoption of in-depth interviews in this stage of the research was justified on two bases: collecting interview data and the need for flexibility. Firstly, in-depth interviews are regarded as one of the more appropriate techniques in exploratory research for collecting inductive data and since knowledge and understanding in this research area is limited, this is an appropriate technique (Carson, Gilmore, Perry \& Gronhaug, 2002; Patton, 2002). This technique not only allows the interviewer to gather preliminary information about the research topic but more specifically to gain insights and understanding regarding the research objectives (Jones, 1985; Kumar, 2005). Secondly, in-depth interviews also allow the interviewer the flexibility to make appropriate changes, drop or add propositions in response to evidence from the interviewees, particularly in relation to information sources used to obtain health related information for healthy eating (Jones, 1985; Minichiello, Aroni \& Hays, 2008). Thus, the interviewer is able to acquire a more valuable insight and understanding through the use of this technique.

This stage of the research process consisted of 12 in-depth interviews with consumers actively seeking health related information for healthy eating, where questions were asked to investigate the appropriateness of those information sources identified in the preliminary framework and from the literature reviewed. The selection of these 12 interviewees was based on judgemental sampling, where they 
were chosen through personal contacts or references from peers or colleagues (Malhotra, 2007; Patton, 2002). The number of interviews was within the recommended number of between eight and 30 (McCracken, 1988; Spradley, 1979), and furthermore theoretical saturation was reached at the 12th in-depth interviews at which point data collected was found not to be adding any new insights, thus the indepth interviews were halted at this stage and no further interviews were conducted (Corbin \& Strauss, 2007; Johnson, 2002).

These interviews were semi-structured in nature, to facilitate flexible and informal discussion, thus allowing the interviewer to gain an in-depth understanding of the interviewees' experiences, opinions and attitudes towards those information sources used to obtain health related information for healthy eating in a regional context. Additional insights from interviewees were sought and the following objectives were also addressed.

- To determine the relevance of the current literature about the research issue in the Australian regional context;

- identify and evaluate information sources which health promoters could concentrate on in order to effectively develop campaigns directed at consumers to further encourage healthy eating; and

- assist in the questionnaire design and hypotheses to be developed in the second stage of this research.

\section{Mail Survey}

A mail questionnaire survey was conducted in the second stage of the research and was justified on two grounds: geographical stratification and anonymity. Firstly, this research has a target sample population that is widely dispersed in the metropolitan area and surrounding region of the Darling Downs (Fowler, 2002). As such, it was more cost effective to administer the questionnaire by mail. Secondly, due to reasons for confidentiality and privacy, respondents could remain anonymous through this mail survey since they could not be matched to those completed questionnaires (Fowler, 2002). Although non-response is a major drawback of using mail survey, this was addressed by a well-designed questionnaire that was relatively short and easy to complete, in a topic that has received considerable public attention in the recent years. In addition, follow-ups on the mail survey and the offering of incentives were intended to improve the response rate.

The mail questionnaire survey was sent out to 800 people to further investigate those information sources identified in the in-depth interviews and the literature. The 
sampling frame adopted was a list of local telephone book subscribers, where respondents were randomly selected using the probability sampling technique. The survey instrument was a self-administered questionnaire distributed by the researcher after it was pre-tested with 12 respondents. Prior to sending out the mail survey and to ensure the adequate well design of the questionnaire, some minor changes were made to the questionnaire based on the feedbacks received from the 12 respondents who had pre-tested it. The questionnaires were returned via a reply paid envelope. The questionnaire was structured into three sections that consisted of 14 questions, aimed at addressing relevant issues and providing data to the following research objectives:

- to identify the information sources by which consumers used to obtain health related information for healthy eating, and

- to determine the relative importance of those information sources used for healthy eating.

\section{Data Analysis}

This research utilised the Statistical Package for the Social Sciences (SPSS) software program, in particular the use of non-parametric techniques (such as the chisquare test and Wilcoxon Signed-Ranked test) to conduct the analysis. The justification for the use of non-parametric relates to the small sample size and the fact that normality was not established in the population distribution (Krebs, 1989). Each of these data analysis techniques is now described.

Chi-square test was used to determine if differences in frequency exist across response categories (Coakes \& Steed, 2007). In this research, this test was used to analyse the respondent's demographic profiles and determine if there were any significant differences between these demographic variables (such as gender, age, qualification and household income) in response to the information sources. On the other hand, the Wilcoxon Signed-Rank test was used to test the magnitude of difference between a pair of information sources where an alpha value indicating less than 0.05 denotes significant difference between the information sources (Coakes \& Steed, 2007). In addition, frequency distribution was used to analyse the demographic and information sources data. Cross tabulation reveals a more concise portrayal of the data captured.

\section{FINDINGS}

Findings from the in-depth interviews revealed some changes to the preliminary framework. While all interviewees agreed with the information sources identified in 
the framework, more than 50 per cent of the interviewees further suggested the inclusion of two information sources (social organisations or societies, and health clubs or gyms) to the framework for further investigation in the second stage of the research. The information sources from the in-depth interviews were subsequently used in stage two of this research to determine their relative importance in obtaining health related information for healthy eating in a regional Australia context.

The second stage of the research achieved a response rate of approximately 32 per cent with 256 responses received from a total of 800 surveys that were sent out. The respondents were predominantly more female (71.1 per cent) than male (28.9 per cent) with the majority of them married (62.11 per cent) and reported as having dependents (approximately 64 per cent) in their household. The age groups and qualifications obtained in the responses were relatively spread across their respective categories, except for the 35-44 years age group and the degree or post graduate qualification, where they accounted 22.66 per cent and 32.03 per cent of the responses respectively. The annual household income groups were also relatively wide and evenly spread in the responses with slightly more than five per cent of the sample indicated their earnings of above AUD\$100,000. Table 1 provides a brief summary of the demographic profiles of the respondents.

The survey investigated 15 information sources; namely personal experiences, friends and relatives, government agencies, health professionals, magazines, newspapers, television, radio, television programmes, internet, brochures, books, food packages, social organisations and societies, and health clubs and gyms. Table 2 briefly illustrates the frequency distribution of the information sources used to obtain health related information for healthy eating in a regional context.

The most important information source used to obtain health related information for healthy eating was friends and relatives that had approximately 94 per cent of the respondents (ie 241 respondents out of a possible of 256) supported it. Respondents regarded this information source as critical (with a mean score of 4.02 out of a possible 5) since they considered friends and relatives to be reliable and trustworthy, to obtain the necessary information that could assist them in making appropriate decisions towards healthy eating. In addition, the convenience of accessing this information source could have also contributed to its importance. 
Table 1 Summary of the demographic profiles

\begin{tabular}{|c|c|c|}
\hline Demographic profiles & Frequency & Percentage \\
\hline \multicolumn{3}{|l|}{ Gender: } \\
\hline Male & 74 & $28.90 \%$ \\
\hline Female & 182 & $71.10 \%$ \\
\hline \multicolumn{3}{|l|}{ Marital status: } \\
\hline Single & 23 & $8.98 \%$ \\
\hline Defacto & 28 & $10.94 \%$ \\
\hline Married & 159 & $62.11 \%$ \\
\hline Divorced & 20 & $7.81 \%$ \\
\hline Widowed & 26 & $10.16 \%$ \\
\hline \multicolumn{3}{|l|}{ Dependents living together: } \\
\hline No & 92 & $35.94 \%$ \\
\hline Yes - One Child & 56 & $21.88 \%$ \\
\hline Yes - Two Children & 79 & $30.86 \%$ \\
\hline Yes - Three or More Children & 29 & $11.33 \%$ \\
\hline \multicolumn{3}{|l|}{ Age: } \\
\hline Under 18 & 4 & $1.56 \%$ \\
\hline $18-24$ & 32 & $12.50 \%$ \\
\hline $25-34$ & 38 & $14.84 \%$ \\
\hline $35-44$ & 58 & $22.66 \%$ \\
\hline $45-54$ & 44 & $17.19 \%$ \\
\hline $55-64$ & 47 & $18.36 \%$ \\
\hline 65 and Over & 33 & $12.89 \%$ \\
\hline \multicolumn{3}{|l|}{ Qualification: } \\
\hline Junior Certificate & 62 & $24.22 \%$ \\
\hline Senior Certificate & 49 & $19.14 \%$ \\
\hline Diploma & 43 & $16.80 \%$ \\
\hline Degree / Post Graduate & 82 & $32.03 \%$ \\
\hline Others & 20 & $7.81 \%$ \\
\hline \multicolumn{3}{|l|}{ Household income: } \\
\hline Under $\$ 25,000$ & 26 & $10.16 \%$ \\
\hline$\$ 25,000-\$ 34,999$ & 57 & $22.27 \%$ \\
\hline$\$ 35,000$ - \$49,999 & 72 & $28.13 \%$ \\
\hline$\$ 50,000-\$ 74,999$ & 51 & $19.92 \%$ \\
\hline$\$ 75,000-\$ 99,999$ & 37 & $14.45 \%$ \\
\hline$\$ 100,000$ or More & 13 & $5.08 \%$ \\
\hline
\end{tabular}

Source: developed for this research 
Table 2 Frequency distribution of the information sources

\begin{tabular}{lccccc}
\hline \multicolumn{1}{c}{ Information sources } & NI & SI & I & VI & EI \\
\hline Friends / Relatives & $3(1.2 \%)$ & $12(4.7 \%)$ & $59(23.0 \%)$ & $86(33.6 \%)$ & $96(37.5 \%)$ \\
\hline Personal Experiences & $14(5.5 \%)$ & $33(12.9 \%)$ & $69(27.0 \%)$ & $89(34.8 \%)$ & $51(19.9 \%)$ \\
\hline Television Programmes & $32(12.5 \%)$ & $23(9.0 \%)$ & $67(26.2 \%)$ & $78(30.5 \%)$ & $56(21.9 \%)$ \\
\hline Magazines & $38(14.8 \%)$ & $33(12.9 \%)$ & $60(23.4 \%)$ & $76(29.7 \%)$ & $49(19.1 \%)$ \\
\hline Newspapers & $41(16.0 \%)$ & $34(13.3 \%)$ & $68(26.6 \%)$ & $55(21.5 \%)$ & $58(22.7 \%)$ \\
\hline Television & $54(21.1 \%)$ & $27(10.5 \%)$ & $65(25.4 \%)$ & $70(27.3 \%)$ & $40(15.6 \%)$ \\
\hline Food Packages & $52(20.3 \%)$ & $44(17.2 \%)$ & $71(27.7 \%)$ & $61(23.8 \%)$ & $28(10.9 \%)$ \\
\hline Health Professionals & $57(22.3 \%)$ & $42(16.4 \%)$ & $68(26.6 \%)$ & $56(21.9 \%)$ & $33(12.9 \%)$ \\
\hline Internet & $63(24.6 \%)$ & $47(18.4 \%)$ & $70(27.3 \%)$ & $52(20.3 \%)$ & $24(9.4 \%)$ \\
\hline Government Agencies & $61(23.8 \%)$ & $55(21.5 \%)$ & $76(29.7 \%)$ & $41(16.0 \%)$ & $23(9.0 \%)$ \\
\hline Brochures & $72(28.1 \%)$ & $46(18.0 \%)$ & $68(26.6 \%)$ & $42(16.4 \%)$ & $28(10.9 \%)$ \\
\hline $\begin{array}{l}\text { Social Organisations / } \\
\text { Societies }\end{array}$ & $90(35.2 \%)$ & $52(20.3 \%)$ & $53(20.7 \%)$ & $34(13.3 \%)$ & $27(10.5 \%)$ \\
\hline Books & $\begin{array}{c}102 \\
(39.8 \%)\end{array}$ & $56(21.9 \%)$ & $48(18.8 \%)$ & $27(10.5 \%)$ & $23(9.0 \%)$ \\
\hline Health Clubs / Gyms & $\begin{array}{c}113 \\
(44.1 \%)\end{array}$ & $79(30.9 \%)$ & $32(12.5 \%)$ & $21(8.2 \%)$ & $11(4.3 \%)$ \\
\hline Radio & $146(5.7 \%)$ & $72(28.1 \%)$ & $20(7.8 \%)$ & $15(5.9 \%)$ & $3(1.2 \%)$ \\
\hline Soure: & & & & \\
\hline
\end{tabular}

Source: developed for this research

Note: NI - Not important, SI - Slightly important, I - Important, VI - Very important, EI - Extremely important

In contrast radio was identified as the least important information source with only approximately 15 per cent of the respondents supported the used of it to obtain health related information for healthy eating. Respondents suggested that this information source had minimal impact (with a mean score of 1.66 out of a possible 5) towards their healthy eating lifestyles or patterns. Table 3 briefly presents the relative importance of the various information sources used to obtain health related information for healthy eating in a regional context and also indicates if significant difference exists between a pair of information sources. 
Table 3 Relative importance of the information sources and the magnitude of difference between a pair of information source variables

\begin{tabular}{|c|c|c|c|}
\hline Information sources & $\begin{array}{l}\text { Mean (1= Not Important, } \\
\text { 5= Extremely Important) }\end{array}$ & \multicolumn{2}{|c|}{$\begin{array}{c}\text { Wilcoxon signed } \\
\text { rank test }\end{array}$} \\
\hline Friends / Relatives & 4.02 & \multirow{2}{*}{$* * *$} & \\
\hline Personal Experiences & 3.51 & & \multirow{2}{*}{ NS } \\
\hline Television Programmes & 3.40 & \multirow{2}{*}{ NS } & \\
\hline Magazines & 3.25 & & \multirow{2}{*}{ NS } \\
\hline Newspapers & 3.21 & \multirow{2}{*}{ NS } & \\
\hline Television & 3.06 & & \multirow{2}{*}{$*$} \\
\hline Food Packages & 2.88 & \multirow{2}{*}{ NS } & \\
\hline Health Professionals & 2.87 & & \multirow{2}{*}{ NS } \\
\hline Internet & 2.71 & \multirow{2}{*}{ NS } & \\
\hline Government Agencies & 2.65 & & \multirow{2}{*}{ NS } \\
\hline Brochures & 2.64 & \multirow[b]{2}{*}{$*$} & \\
\hline $\begin{array}{l}\text { Social Organisations / } \\
\text { Societies }\end{array}$ & 2.44 & & \multirow[t]{2}{*}{ NS } \\
\hline Books & 2.27 & \multirow{2}{*}{$* * *$} & \\
\hline Health Clubs / Gyms & 1.98 & & \multirow{2}{*}{$* * *$} \\
\hline Radio & 1.66 & & \\
\hline
\end{tabular}

Source: developed for this research

Note: NS refers to no significant difference between information sources.

Whilst $* P<0.05 ; * * P<0.01 ; * * P<0.001$ denote a significant difference between information sources.

On the whole, respondents were relatively consistent in their responses to the importance of the different information sources used to obtain health related information for healthy eating. Findings (as shown in Table 3 column 3) revealed no significant differences existed in the majority of the information sources; namely between (1) personal experiences and television programmes, (2) television programmes and magazines, (3) magazines and newspapers, (4) newspapers and television, (5) food packages and health professionals, (6) health professionals and the internet, (7) the internet and government agencies, and (8) social organisations / societies and books. However, the results did indicate notable significant differences between five pairs of information sources; (1) friends / relatives and personal experiences, (2) television and food packages, (3) brochures and social organisations / societies, (4) books and health clubs / gyms, and (5) health clubs / gyms and radio.

In addition, the findings also showed significant differences between gender, age, qualification and household income groups. In the gender group, it was noted that male respondents preferred the use of newspapers while female respondents would 
favour television programmes, food packages and social organisations and societies, to obtain health related information for healthy eating. On the other hand, respondents in the 25 to 34 age group regarded the internet and health clubs/gyms as important sources of information whereas respondents in the age group between 35 to 44 would prefer television programmes. Health professionals and social organisations and societies were information sources highly sought after by respondents between 55 to 64 years of age.

Table 4 Relative importance of information sources used to obtain health related information for healthy eating: Mann-Whitney test of difference between male and female

\begin{tabular}{lc}
\hline \multicolumn{1}{c}{ Information sources } & Mann-Whitney test of difference \\
\hline Friends / Relatives & NS \\
\hline Personal Experiences & NS \\
\hline Television Programmes & $*$ \\
\hline Magazines & NS \\
\hline Newspapers & $*$ \\
\hline Television & NS \\
\hline Food Packages & $* *$ \\
\hline Health Professionals & NS \\
\hline Internet & NS \\
\hline Government Agencies & NS \\
\hline Brochures & NS \\
\hline Social Organisations / Societies & $*$ \\
\hline Books & NS \\
\hline Health Clubs / Gyms & NS \\
\hline Radio & NS \\
\hline Souce: developed for this research
\end{tabular}

Source: developed for this research

Note: NS refers to no significant difference between male and female.

Whilst $* P<0.05 ; * * P<0.01 ; * * * P<0.001$ denote $s$ a significant difference between male and female.

Respondents with degree and post graduate qualifications were more likely to seek out food packages and health professionals as information sources for healthy eating whilst respondents with lower qualifications would prefer television instead. For household income; respondents with a household income of $\$ 35,000$ to $\$ 49,999$ would generally use newspapers to obtain health related information for healthy eating while respondents with a household income of $\$ 50,000$ to $\$ 74,999$ would favour information sources such as health clubs and gyms and food packages. Television programmes and magazines were the desired information sources for 
respondents with a household income of $\$ 75,000$ to $\$ 99,999$. The differences in these respective groups were presented in tables $4,5,6$ and 7 . The variation could be explained by respondents' overall level of healthy eating experiences and also their attitudes and perceptions towards health related information search and sources.

Table 5 Relative importance of information sources used to obtain health related information for healthy eating: Kruskal-Wallis test of difference between age groups

\begin{tabular}{lc}
\hline \multicolumn{1}{c}{ Information sources } & Kruskal-Wallis test \\
\hline Friends / Relatives & $\mathrm{NS}$ \\
\hline Personal Experiences & $\mathrm{NS}$ \\
\hline Television Programmes & $\mathrm{NS}$ \\
\hline Magazines & $\mathrm{NS}$ \\
\hline Newspapers & $\mathrm{NS}$ \\
\hline Television & $\mathrm{NS}$ \\
\hline Food Packages & $*$ \\
\hline Health Professionals & $* *$ \\
\hline Internet & $\mathrm{NS}$ \\
\hline Government Agencies & $\mathrm{NS}$ \\
\hline Brochures & $*$ \\
\hline Social Organisations / Societies & $\mathrm{NS}$ \\
\hline Books & $* *$ \\
\hline Health Clubs / Gyms & $\mathrm{NS}$ \\
\hline Radio & \\
\hline
\end{tabular}

Source: developed for this research

Note: NS refers to no significant difference between age groups.

Whilst $* P<0.05 ; * * P<0.01 ; * * * P<0.001$ denote a significant difference between age groups.

\section{CONCLUSIONS AND IMPLICATIONS}

In conclusion, this study investigated 15 information sources that consumers used to obtain health related information for healthy eating in an Australian regional context. The survey results indicated that friends and relatives were the most important information source used to obtain health related information whilst radio was seen as the least influential in the information search process.

The results (as shown in Table 3) highlighted the relative importance of those information sources and provided consumers with a list of sources to which they could seek out for, to obtain health related information for healthy eating. In accordance to their differing circumstances, consumers are able to take into consideration those information sources investigated in this study and determine the relevance of the 
sources that needed further consideration during their information search process, which then lead to healthier eating.

Table 6 Relative importance of information sources used to obtain health related information for healthy eating: Kruskal-Wallis test of difference between qualification groups

\begin{tabular}{ll}
\hline \multicolumn{1}{c}{ Information sources } & Kruskal-Wallis test \\
\hline Friends / Relatives & NS \\
\hline Personal Experiences & NS \\
\hline Television Programmes & NS \\
\hline Magazines & NS \\
\hline Newspapers & $*$ \\
\hline Television & $* *$ \\
\hline Food Packages & NS \\
\hline Health Professionals & NS \\
\hline Internet & NS \\
\hline Government Agencies & NS \\
\hline Brochures & NS \\
\hline Social Organisations / Societies & NS \\
\hline Books & NS \\
\hline Health Clubs / Gyms & \\
\hline Radio & \\
\hline Source: developed for this research & \\
Note: $N S$ refers to no significant difference between qualification groups. & \\
Whilst $* P<0.05 ; * * P<0.01 ; * * P<0.001$ denote a significant difference between qualification groups.
\end{tabular}

In addition, the findings also had managerial implications (eg allocation of appropriate resources) that could assist health promoters (including public and commercial entities) in identifying the key sources of health information that consumers used to obtain health related information for healthy eating. With this, health promoters could evaluate and determine the most appropriate information sources for which they believed their advertising spending and campaigns directed at specific consumer groups could be adequately spent and justified, to further encourage healthy eating. Through market segmentation (for example via gender, age, qualification and household income groups) health promoters could focus their efforts and attention on the most appropriate and effective information sources to develop campaigns and deliver the intended marketing messages to their targeted market segments. For example in gender segmentation, it appeared to be more effective for health promoters to use newspapers on males while females seemed to be more 
receptive with television programmes (eg "What's Good For You”), food packages and social organisations and societies as their preferred information sources. When considering different age groups, health promoters should consider the internet, and health clubs and gyms (eg "Fitness Works) as more useful information sources for consumers between 25 to 34 years of age and should regard television programmes as an important information source for the age group 35 to 44 years. In contrast, health professionals, and social organisations and societies were information sources that health promoters should concentrate their marketing efforts in for consumers between 55 to 64 years of age.

Table 7 Relative importance of information sources used to obtain health related information for healthy eating: Kruskal-Wallis test of difference between household income groups

\begin{tabular}{ll}
\hline \multicolumn{1}{c}{ Information sources } & Kruskal-Wallis test \\
\hline Friends / Relatives & $\mathrm{NS}$ \\
\hline Personal Experiences & NS \\
\hline Television Programmes & $*$ \\
\hline Magazines & $*$ \\
\hline Newspapers & $\mathrm{NS}$ \\
\hline Television & $* *$ \\
\hline Food Packages & $\mathrm{NS}$ \\
\hline Health Professionals & $\mathrm{NS}$ \\
\hline Internet & $\mathrm{NS}$ \\
\hline Government Agencies & $\mathrm{NS}$ \\
\hline Brochures & $\mathrm{NS}$ \\
\hline Social Organisations / Societies & $\mathrm{NS}$ \\
\hline Books & $*$ \\
\hline Health Clubs / Gyms & $\mathrm{NS}$ \\
\hline Radio & \\
\hline Source: developed for this research \\
Note: NS refers to no significant difference between household income groups. Whilst $* P<0.05 ; * * P$ \\
$0.01 ; * * P<0.001$ denote a significant difference between household income groups.
\end{tabular}

Looking at qualifications, health promoters should regard food packages and health professionals as important information sources for consumers who are highly educated (ie with degree or post graduate qualifications), whilst television appeared to be more influential on consumers with lower qualifications. In segmenting the markets by household income, the use of newspapers by health promoters could prove to be more effective on income group of $\$ 35,000$ to $\$ 49,999$, while greater emphasis should 
be placed on health clubs and gyms, and food packages as key information sources for income group $\$ 35,000$ to $\$ 49,999$. In terms of the higher income group of $\$ 75,000$ to $\$ 99,999$, health promoters could possibly achieve greater success by focusing on information sources such as television programmes, and magazines.

The findings of this study have extended the existing literature of health related information search with the identification of two additional information sources (social organisations and societies, and health clubs and gyms) for which consumers could use when selecting their food choices for healthy eating. In addition, new insights to the literature have been added with the results revealing no one category of the information sources (intrapersonal, interpersonal, and media and commercial) is considered to be more or less important than the other category. Another theoretical contribution of this study is that it supports and enhances the preliminary framework linking information sources to healthy eating, and adding a geographical dimension by applying this established framework in the regional Australia context.

\section{LIMITATIONS AND RECOMMENDATIONS FOR FURTHER RESEARCH}

This research study investigated only the Darling Downs region in Queensland, Australia and thus the findings could not be generalised to the population at large. In order to generalise the findings, a more representative sampling population should be sought and be tested in another Australian regional setting. Using the findings from this study as the basis, further investigation could also be conducted in other Australian capital cities, to determine if any significant differences existed between capital and regional settings on the information sources used to obtain health related information for healthy eating. In addition, further research could be conducted in other countries so that comparison of the findings could be made from different country perspectives.

\section{REFERENCES}

Abbott, R. (1997). Food and nutrition information: A study of sources, uses, and understanding. British Food Journal, 90(2), 43-49.

Australian Bureau of Statistics. (2008). Overweight and Obesity in Adults, Australia, 2004-05. $\quad 14$ Fetrieved February, 2011, from http://www.abs.gov.au/ausstats/abs@.nsf/Latestproducts/4719.0Main\%20Feature s22004-05 ?opendocument\&tabname=Summary\&prodno=4719.0\&issue=200405\&num=\&view 
Access Economics. (2006). The Economic Costs of Obesity. Canberra, Australia: Access Economics.

ACNielson. (2005). We want healthy food and we want it now. Retrieved 14 February, 2011, from http://uk.nielsen.com/insights/healthy_v_convenience.shtml

Bell, C. (2008). Inquiry into obesity in Australia: Local solutions for preventing childhood overweight and obesity in regional Australia. Retrieved 14 February, 2011, from

http://www.aph.gov.au/House/committee/haa/obesity/subs/sub128.pdf

Berland, G. K., Elliott, M. N., Morales, L. S., Algazy, J. I., Kravitz, R. L., Broder, M. S., Kanouse, D. E., Muñoz, J. A., Puyol, J. A., Lara, M., Watkins, K. E., Yang, H., \& McGlynn, E. A. (2001). Health information on the Internet: accessibility, quality, and readability in English and Spanish. The Journal of the American Medical Association, 285(20), 2612-2621.

Beuchat, L. R. (2002). Ecological factors influencing survival and growth of human pathogens on raw fruits and vegetables. Microbes and Infection, 4(4), 413-423.

Biloukha, O. O., \& Utermohlen, V. (2001). Healthy eating in Ukraine: Attitudes, barriers and information sources. Public Health Nutrition, 4(2), 207-215.

Borzekowski, D. L. G., \& Rickert, V. I. (2001). Adolescent cybersurfing for health information: A new resource that crosses barriers. Pediatrics \& Adolescent Medicine, 155(7), 813-817.

Brown, J. D., \& Walsh-Childers, K. (1994). Effects of media on personal and public health. In B. Jennings \& D. Zillmann, (Eds.), Media effects: Advances in theory and research (pp. 389-415). Hillsdale, NJ: Erlbaum.

Carson, D., Gilmore, A., Perry, C., \& Gronhaug, K. (2002). Qualitative Marketing Research. London, England: Sage Publications.

Coakes, S. J., \& Steed, L. G. (2007). SPSS: Analysis without anguish: version 14.0 for Windows. Brisbane: John Wiley \& Sons Australia Ltd.

Corbin, J., \& Strauss, A. (2007). Basics of qualitative research ( $3^{\text {rd }}$ ed.). Thousands Oaks, CA: Sage Publications.

Courtright, C. (2004). Health information-seeking among Latino newcomers: an exploratory study. Information Research, 10(2), paper 224. Retrieved 11 May, 2011, from http://InformationR.net/ir/10-2/paper224.html

De Almeida, M. D., Graca, P., Lappalainen, R., Giachetti, I., Kafatos, A., De Winter, A. R., \& Kaerney, J. M. (1997). Sources used and trusted by nationally representative adults in the European Union for information on healthy eating. European Journal of Clinical Nutrition, 51(2), S16-S22. 
Dibsdall, L. A., Lambert, N., Bobbin, R. F., \& Frewer, L. J. (2003). Low-income consumers' attitudes and behaviour towards access, availability and motivation to eat fruit and vegetables. Public Health Nutrition, 6(2), 159-168.

Dutta-Bergman, M. J. (2004). Primary sources of health information: Comparisons in the domain of health attitudes, health cognitions, and health behaviors. Health Communication, 16(3), 273-288.

Evans, D. W., Necheles, J., Longjohn, M., \& Christoffel, K. K. (2007). The 5-4-3-2-1 Go! Intervention: Social marketing strategies for nutrition. Journal of Nutrition Education and Behavior, 39(2), S55-S59.

Eysenbach, G., \& Köhler, C. (2002). How do consumers search for and appraise health information on the world wide web? Qualitative study using focus groups, usability tests, and in-depth interviews. BMJ, 324(7337), 573-577.

Eysenbach, G., Powell, J., Kuss, O., \& Sa, E. R. (2002). Empirical studies assessing the quality of health information for consumers on the world wide web: A systematic review. The Journal of the American Medical Association, 287(20), 2691-2700.

Ford, G. T., Hastak, M., Mitra, A., \& Ringold, D. J. (1996). Can consumers interpret nutrition information in the presence of a health claim? A laboratory investigation. Journal of Public Policy \& Marketing, 15(1), 16-27.

Fowler, F. J. (2002). Survey research methods ( $3^{\text {rd }}$ ed.). Thousand Oaks, California: Sage Publications Inc.

Freeland-Graves, J., \& Nitzke, S. (2003). Position of the American dietetic association: Total diet approach to communicating food and nutrition information. Journal of the American Dietetic Association, 107(7), 1224-1232.

Freimuth, V. S., Stein, J. A., \& Kean, T. J. (1989). Searching for health information: The cancer information service model. Philadelphia: University of Pennsylvania Press.

Gardner, H. (2000). Intelligence reframed: Multiple intelligences for the 21st century, New York: Basic Books.

Garretson, J. A., \& Burton, S. (2000). The nutrition facts panel and package claims: The role of nutrient values, multiple claims, and congruent information on attitudes, disease-related risks, and consumer trust. Journal of Public Policy \& Marketing, 19(2), 213-227.

Glanz, K., \& Hoelscher, D. (2004). Increasing fruit and vegetable intake by changing environment, policy and pricing: restaurant-based research, strategies, and recommendations. Preventive Medicine, 39(2), S88-S93. 
Gray, N. J., Klein, J. D., Noyce, P. R., Sesselberg, T. S., \& Cantrill, J. A. (2005). Health information-seeking behaviour in adolescence: the place of the internet. Social Science \& Medicine, 60(7), 1467-1478.

Ip, J., Mehta, K. P., \& Coveney, J. (2007). Exploring parents' perceptions of television food advertising directed at children: A South Australian study. Nutrition and Dietetics, 64(1), 50-58.

Johnson, J. M. (2002). In-depth Interviewing. In J. F. Gubrium \& J. A. Holstein (Eds.), Handbook of Interview Research: Context \& Method (pp. 103-120). Thousand Oaks, California: Sage Publications, Inc.

Jones, S. (1985). Depth Interviewing. In R. Walker (Ed.), Applied qualitative research (pp. 45-55). London, England: Gower Publishing Limited.

Kearney, J. M., \& McElhone, S. (1999). Perceived barriers in trying to eat healthier results of a pan-EU consumer attitudinal survey. British Journal of Nutrition, 81(2), S133-S137.

Kerstetter, D., \& Cho, M. (2004). Prior Knowledge, credibility and information search. Annals of Tourism Research, 31(4), 961-985.

Kozup, J. C., Creyer, E. H., \& Burton, S. (2003). Making healthful food choices: The influence of health claims and nutrition information on consumers' evaluations of packaged food products and restaurant menu items. Journal of Marketing, 67(2), 19-34.

Krebs, C. J. (1989). Ecological methodology. New York: Harper and Row.

Kreuter, M. W., Chheda, S. G., \& Bull, F. C. (2000). How Does Physician Advice Influence Patient Behavior? Evidence for a Priming Effect. Archives of Family Medicine, 9(5), 426-433.

Kumar, R. (2005). Research methodology: A step-by-step guide for beginners $\left(2^{\mathrm{nd}}\right.$ ed.). Thousand Oaks, California: Sage Publications.

Lambert, S. D., \& Loiselle, C. G. (2007). Health information - Seeking behaviour. Qualitative Health Research, 17(8), 1006-1019.

Lappalainen, R., Kearney, J., \& Gibney, M. (1998). A pan EU survey of consumer attitudes to food, nutrition and health: An overview. Food Quality and Preference, 9(6), 467-478.

Malhotra, N. K. (2007). Marketing research: An applied orientation ( $5^{\text {th }}$ ed.). London: Prentice-Hall International.

Marshall, D., Anderson, A., Lean, M., \& Foster, A. (1994). Healthy eating: Fruits and vegetables in Scotland. British Food Journal, 96(7), 18-24.

McCracken, G. (1988). The Long Interview. Newbury Park, CA: Sage Publications. 
Minichiello, V., Aroni, R., \& Hays, T. (2008). In-depth interviewing: principles, techniques, analysis ( $3^{\text {rd }}$ ed.). New South Wales, Australia: Pearson Education Australia.

Nestle, M., \& Jacobson, M. F. (2000). Halting the obesity epidemic: A public health policy approach. Public Health Reports, 115(1), 12-24.

Patton, M. Q. (2002). Qualitative research and evaluation methods (3 ${ }^{\text {rd }}$ ed.). Thousand Oaks, California: Sage Publications.

Povey, R., Conner, M., Sparks, P., James, R., \& Shepherd, R. (1998). Interpretations of healthy and unhealthy eating, and implications for dietary change. Health Education Research, 13(2), 171-183.

Punj, G. N., \& Steward, D. W. (1983). An interaction framework of consumer decision making. The Journal of Consumer Research, 10(2), 181-196.

Reger, B., Wootan, M. G., \& Booth-Butterfield, S. (1999). Using mass media to promote healthy eating: A community-based demonstration project. Preventive Medicine, 29(5), 414-421.

Reid, D. J., \& Hendricks, S. (1993). Consumer awareness of nutrition information on food package labels. Journal Canadian Dietetic Association, 54(3), 127-131.

Risk, A., \& Dzenowagis, J. (2001). Review of internet health information quality initiatives. Journal of Medical Research, 3(4), e28.

Risk, A., \& Petersen, C. (2002). Health information on the internet: Quality issues and international initiatives. The Journal of the American Medical Association, 287(20), 2713-2715.

Schwarz, N. (2004). Metacognitive experiences in consumer judgment and decision making. Journal of Consumer Psychology, 14(4), 332-348.

Shepherd, J., Harden, A., Rees, R., Brunton, G., Garcia, J., Oliver, S., \& Oakley, A. (2006). Young people and healthy eating: a systematic review of research on barriers and facilitators. Health Education Research, 21(2), 239-257.

Spradley, J. P. (1979). The Ethnographic Interview (1 ${ }^{\text {st }}$ ed.). New York, USA: Wadsworth Publishing.

Srinivasan, N. (1990). Pre-purchase external information search for information. In V. Zeithaml (Ed.), Review of marketing (pp. 153-189). Chicago, IL: American Marketing Association.

St Leger, L. H. (1999). The opportunities and effectiveness of the health promoting primary school in improving child health - A review of the claims and evidence. Health Education Research, 14(1), 51-69. 
Story, M. T., Neumark-Stzainer, D. R., Sherwood, N. E., Holt, K., Sofka, D., Trowbridge, F., \& Barlow, S. E. (2002). Management of child and adolescent obesity: Attitudes, barriers, skills, and training needs among health care professionals. Pediatrics, 110(1), 210-214.

Szwajcer, E. M., Hiddink, G. J., Koelen, M. A., \& Van Woerkum, C. (2005). Nutrition-related information-seeking behaviours before and throughout the course of pregnancy: Consequences for nutrition communication. European Journal of Clinical Nutrition, 59(1), S57-S65.

Theodosiou, L., \& Green, J. (2003). Emerging challenges in using health information from the internet. Advances in Psychiatric Treatment, 9(5), 387-396.

Thorburn, A. W. (2005). Prevalence of obesity in Australia. Obesity Review, 6(3), 187-189.

Urbany, J. E., Dickson, P. R., \& Wilkie, W. L. (1989). Buyer uncertainty and information search. The Journal of Consumer Research, 16(2), 208-215.

Veldre, D. (2005, August). Television dominates regional ad spend. B\&T, 12.

Verplanken, B., \& Faes, S. (1999). Good intentions, bad habits, and effects of forming implementation intentions on healthy eating. European Journal of Social Psychology, 29(5-6), 591-604.

Warner, D., \& Procaccino, J. D. (2004). Toward wellness: Women seeking health information. Journal of the American Society for Information Science and Technology, 55(8), 709-730.

Worsley, A. (1989). Perceived reliability of sources of health information. Health Education Research, 4(3), 367-376.

Young, I. (1993). Healthy eating policies in schools: An evaluation of effects on pupils’ knowledge, attitudes and behaviour. Health Education Journal, 52(1), 3-9. 